\title{
Platelet Count 20000
}

National Cancer Institute

\section{Source}

National Cancer Institute. Platelet Count 20000. NCI Thesaurus. Code C53266.

Indicates a platelet count of at least 20,000 per cubic millimeter. 